DIMENSI, VOL. 8 , NO. 1 : 176-185

MARET 2019

ISSN: 2085-9996

\title{
Pengaruh Teknik Mind Mapping Terhadap Keterampilan Menulis Siswa
}

\section{The Effect of Mind Mapping Technique Toward Students' Writing Skill}

\author{
Rebecha Aprilia ${ }^{1}$, Sulastri Manurung ${ }^{2}$ \\ ${ }^{1}$ (English Education Department,University of Riau Kepulauan, Indonesia) \\ ${ }^{1}$ rebechaaprilia@gmail.com ${ }^{2}$ lastrimanurung15@gmail.com
}

\begin{abstract}
Abstrak
Penelitian ini bertujuan untuk menemukan apakah ada pengaruh teknik Mind Mapping terhadap keterampilan siswa dalam menulis teks deskriptif pada siswa kelas 10 SMK Management Training System tahun akademik 2018-2019. Desain penelitian menggunakan metode kuantitatif dan metode penelitian merupakan quasi experimental design yaitu non equivalent control group design yang terdiri dari dua kelas yaitu kelas eksperimen dan kelas control. Kelas experiment diberi perlakuan dengan menggunakan teknik mind mapping. Data penelitian diperoleh dari hasil pre-test dan post-test pada kelas eksperimen dan kelas kontrol. Hasil penelitian menunjukkan skor siswa di kelas eksperimen memperoleh nilai tertinggi dengan nilai 91 dan nilai terendah 9. Nilai $t_{\text {observe }}$ lebih tinggi dari $t_{\text {table }}(2.759$ > 2.074). Dengan demikian, Ho ditolak dan Ha diterima. Sehingga dapat disimpulkan bahwa teknik Mind Mapping berpengaruh signifikan terhadap keterampilan menulis teks deksripsitf siswa. Teknik Mind Mapping juga membantu siswa untuk berfikir lebih creative dalam mengembangkan ide-idenya, mengembangkan konsep serta lebih rileks dalam pelaksanaan pembelajaran khususnya menulis.
\end{abstract}

Kata Kunci; mind mapping, menulis, teks deskriptif, keterampilan

\begin{abstract}
The study aims to find out the effect of Mind Mapping technique towards students' skill in writing descriptive text at tenth grade students Vocational High School Management Training System in academic year 2018-2019. The research design was quantitative method and the research method was quasi experimental design namely non-equivalent control group design which consists of two classes; experiment class and control class. Experiment class was treated using mind mapping technique. The research data was obtained through pre-test and post-test both at experiment class and control class. The research finding shows students' highest score in experiment class was 91 and the lowest score was

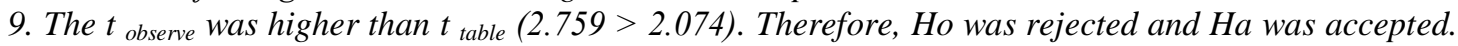
Thus, it can be concluded that Mind Mapping technique has significant effect towards students' writing descriptive text skill. Mind mapping technique also helped students to think more creatively in developing their ideas, developing concepts, and more relax in learning activity especially in writing.
\end{abstract}

Keywords: mind mapping, writing, descriptive text, skill

\section{INTRODUCTION}

Writing is one of the important language skills that should be mastered by language learners as it is relevant in many aspects of life such as communication, education, transactions, etc. Sakolik (in Linse 2005: 98) claimed that writing is a 
combination of process and product. The process refers to the act of gathering ideas and working with them until they are presented in a manner that is polished comprehensible to readers. Writing requires complex process and knowledge to achieve a successful writing. Therefore, writing is assumed as a difficult language skill and many students faced some problems to produce cohesive and coherent paragraphs/ texts especially for novice writers. Cheung (2016:7) states in the writing/revising stage, novice writers often have difficulty in deciding what say next (in the next sentence). They tend to re-read the previous sentence/clause before they decide how to proceed. Moreover, creativity, lack of vocabulary, and inappropriate teaching technique also contribute as barriers for students and teachers in teaching learning writing.

Writing descriptive text, as one of the type of texts taught at Vocational school, requires an ability to present the image of things (animal, people, object, and phenomenon) naturally. Wyrick (1987: 227) said the writer of description creates a word of pictures, places, objects, and emotions using a careful selection of detail to make an impression on the reader. Therefore, mind mapping can be used as a useful teaching technique to overcome the problems. The researcher assumed by applying an appropriate teaching technique named mind mapping technique would help students to improve their writing skill particularly in writing descriptive text.

According to Rustler (2012:1) Mind Mapping is a visual technique for structuring and organizing thoughts and ideas. This technique can make students easily to remember things which they want to describe. It can be supported with several things such as color pencil, paper, picture, etc. Thus, the purpose of research was to find out whether there is an effect of mind mapping technique toward students' writing skill in descriptive text at first grade Management Training System Vocational School in academic year of 2018/2019.

\section{Writing}

According to Brown (2001: 336) "writing is thinking process, because writing is a process of putting ideas down on paper to transform thought into words and give 
them structure and coherent organization". Writing is one of the most significant cultural accomplishments of human being (Rogers, 2005: 1). From the definitions above, it can be concluded that writing is the way in thinking process by using some aspects such as graphic symbol to show idea, message, or expression, and transform it into structure on the paper.

\section{Types of writing}

According to Brown (2004: 220) there are four types of writing, they are:

\section{Imitative}

It is written language that learner must achieve basic tasks of writing letters, words,punctuation, and very simple sentences. This category includes the ability to spell correctly and to perceive phoneme-grapheme correspondences in the English

spelling system. It is a level at which learners are trying to master the mechanics of writing. At this stage, the first primary is not exclusive focus, while context and meaning are of secondary concern.

\section{Intensive (controlled)}

It is a type producing appropriate vocabulary within a context, collocations andidioms, and correct grammatical features up to the length of a: sentence. The context meaning is importance in determining correctness and appropriateness, but most assessment tasks are more a focus on form.

\section{Responsive}

It required with the learners to perform at a limited discourse level, connectingsentences into a paragraph and creating a logically connected sequence of two or three paragraphs. Genres of writing include brief narratives and descriptions, short reports, lab reports, summaries, brief responses to reading, and interpretations of charts or graphs. It is more focused on the discourse conventions that will achieve the objectives of the written text. Form-focused attention is mostly at the discourse level, with a strong emphasis on context and meaning. 


\section{Extensive}

Extensive writing implies successful management of all the processes and strategiesof writing for all purposes, up to the length of an essay, a term paper, a major research project report, or even a thesis. It is focused on achieving a purpose, organizing and developing ideas logically, using details to support or illustrate ideas, demonstrating syntactic and lexical variety, and in many cases, engaging in the process of multiple drafts to achieve a final product. Extensive is focused on grammatical form is limited to occasional editing or proofreading of a draft.

\section{Mind Mapping Technique}

Visual mapping is known by many other names, most notably Mind mapping, but also concept mapping, flow-charting, visual thinking, spider diagramming, memory mapping, semantic mapping, and thought webbing. Regardless of what you call it, the basic principles are the same (Krasnic, 2011: 48). A visual map is a graphic tool used to collect, create, manage, and exchange information. It represents information via the spatial organization of concepts/topics, ideas, words, or other items linked to and arranged in a radial pattern around a central concept. Mind mapping helps you gain a better overview and makes new connections more visible so you can create an infinite number of thoughts, ideas and associations on any topic - perfect for fostering creativity and generating new ideas whenever the mood takes you.Thus, according to Rustler (2012: 46-47) mind mapping as a brain-friendly technique because it contains visual elements and is itself like one large picture that can quickly and easily memorize and understand.

There are some steps in Mind Mapping Technique according to Krasnic (2011: 29-72), they are:

1. Select the concept, topic, or subject to map.

2. Gather all the relevant information.

3. Keep the map simple, concise, relevant, accurate, complete, logical and clear.

4. Start in the center with the central concept.

5. Add primary concept on the branches connected to the central concept. 
6. Branch sub concepts off the primary concept to elaborate and clarify.

7. Continue to capture and map key concept, recognize, and edit, as needed.

8. Add more information - provided it adds value - to the key concepts that already mapped.

9. Add visual elements and formatting to increase the map's effectiveness.

10. Go through the visual map checklist for any final edits.

According to Spoorthi et al (2013), the advantages of mind mapping are:

1. Mind mapping helps to think more concentrate because both sides of brain are active at the same time that can help to draw together which helps in comprehension and memorization.

2. Mind mapping will help to classify relevant concepts / information, and making the information more complex to think and put on paper.

3. Mind mapping can make people becomes more creative because it uses brainstorming.

4. Mind mapping uses keywords / symbols, graphs to draw ideas, it becomes faster when compared to write down lines of notes.

Based on the clarification above, the researcher concludes that mind mapping is apowerful tool for assisting any form of writing. It allows students to get the ideas and key facts down andat the same time organizes them in meaningful ways. Mind mapping can be used to help and organize thinking before start writing or get stuck into a project. It can develop all ideas and see where they relate to each other before deciding the best way to go about things.

\section{Disadvantages of Mind Mapping}

According to Spoorthi et al (2013) the disadvantages of mind mapping are as follow:

1. It is difficult to change from linear system of note taking which everybody is taught since their childhood to a very different way. It requires great effort.

2. It is difficult to develop a good thought from a completely new topic.

3. If not got an idea, may be can frustrating because of lack of space, lack of creative thinking etc. 
4. Mind mapping may not always be easier than linear note taking.

Based on the clarification above, the researcher conclude that there are some disadvantages of mind mapping, but we have to use this technique maximally so that it can give a good implementation on writing.

\section{Descriptive Text}

According to Gerot and Wignel (2008) in Adam (2017:167), descriptive text is a text type that describes a particular person, place, or things. The text lists the characteristics about something, its purpose is to describe a particular person, animal, place or thing. The generic structure in descriptive text consists two parts. First is identification, in this part there is a topic that will be described. Second is description, in this part there is description that clarifies the topic such as the phenomenon, characteristic, etc.

\section{METHODOLOGY}

The design of this research is experimental design. According to Best in Pandey (2015:90) "Experimental research is the description and analysis of what will be or what willoccur, under carefully controlled condition". Its purpose was to know the effect of different treatment in a group with another group. This research conducted at first grade students of SMK Management Training System Batam in academic year 2018/2019, it is located at Komplek Grand California Block B1/1-4 \& B2/9-11 Batam Centre. It held on August 2018.

There were 28 students registered at first year students of SMK Management Training System Batam in academic year 2018/2019 as population of this study. The sample of this study was experimental class which consist 12 students and control class which also consisted of 12 students. Both of classes were assigned to write descriptive text as a written test. In experimental study explained the relationship among variables that manipulated and measured. The researcher used two groups. They were experimental group and control group. Then, the experimental group received the treatment by using mind mapping technique. The control group received the treatment by using keyword technique. The researcher used cluster purposive sampling, because 
the sample that has been taken based on the amount of student every class. According to Ilkeret all (2006) the purposive sampling technique, also called judgment sampling, is the deliberate choice of a participant due to the qualities the participant possesses.

\section{RESULTS}

The data were obtained by giving two tests, there were pre-test and post-test on both experimental and control group. The writer used analytic scoring assessment to assess the students' writing that based on organization, content, grammar, punctuation, spelling, mechanic, and vocabulary where each component had its score.

Based on the validity test, data were valid. It aimed to the syllabus of the school in vocational school. The instruction test was appropriate with the main competence (KI), base competence (KD) and indicators of competence achievement (IPK) based on the validator'sverification. The essence competence that was used from the essence competence 4 and base competence 4.4.2, with indicators of competence achievement was to make a descriptive text by using generic structure in Mind Mapping technique.

The researcher used Shapiro Wilk test in SPSS statistic 20 to perform normality test by comparing the distribution of the data to be tested normality with the distribution of standard data. Based on normality and homogeneity test, the data in both control and experimental was normal because the score normality and homogeneity in control and experiment group more than 0.05 .

From the data analysis, the students' score in experimental class achieved better result with the highest score was 91, meanwhile the lowest score was 9. In this research, the researcher used independent samples test on SPSS statistics 20 to do ttest. Here the result of independent test in experimental group. 
Tabel. 1. Independent Test in Experimental Group

Independent Samples Test

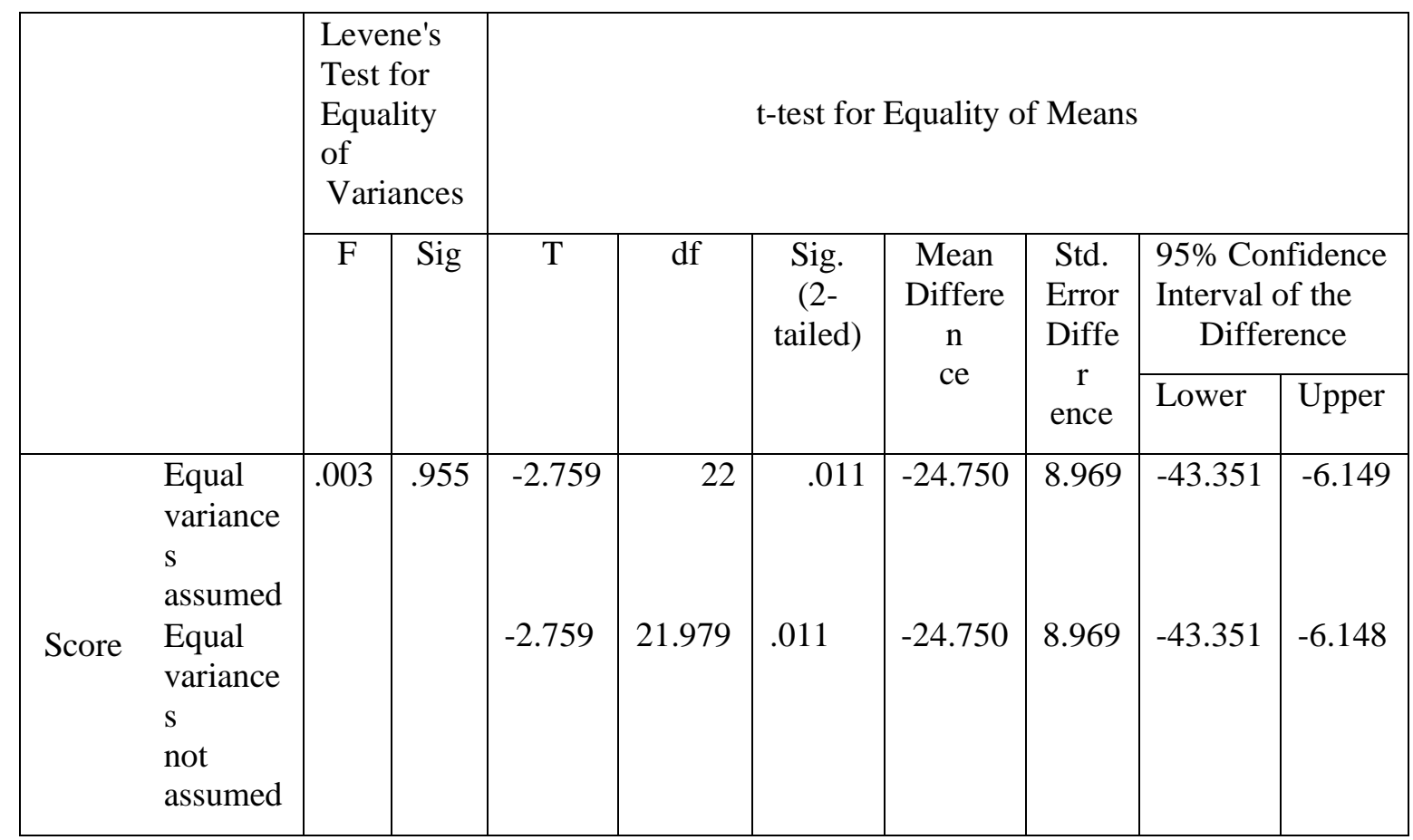

To find the hypothesis, from the table of independent test of pre-test and posttest above, the mean difference score was negative $(-24.750)$ based on equal variances assumed. The table above also shows that $\mathrm{t}$ observe was -2.759 compared with $\mathrm{t}_{\text {table }}$ with $\mathrm{dk}=\mathrm{n}_{1}+\mathrm{n}_{2}-2=12+12-2=24-2=22$ in significance $5 \%, \mathrm{t}$ table (2.074). It shows

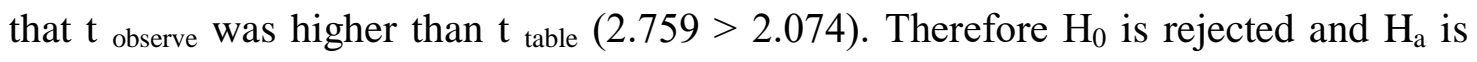
accepted, it means there was significant difference before and after taught by using Mind Mapping technique in experimental group. In fact, based on independent sample test, there was significant effect before and after taught by using Mind Mapping in experimental group. While in control group, there was no significant effect before and after taught by using keyword technique. It can be concluded that Mind Mapping technique is more effective to improve students' writing skill. 


\section{DISCUSSION}

As mentioned previously, the research aimed to discover the effect of mind mapping technique towards students' writing skill. Thus, in the following the objective will be touched open.

Regarding to the research question, the obtained result based on independent test showed there was significant effect between pre-test and post-test in experimental group. Because $t$ observe was higher than $t_{\text {table }}(2.759>2.074)$, it means $\mathrm{H}_{0}$ is rejected and $\mathrm{H}_{\mathrm{a}}$ is accepted. It can be concluded that Mind Mapping gave significant effect and was effective in improving students' ability in writing descriptive text. The result is consistent with those previous researches of Nurlaila (2013), Khoiriyah (2014), and Buran \& Filyukov (2015).

The study reveals Mind mapping technique wasable to make students more enjoyable during teaching and learning process in experiment class. In learning process by using mind mapping technique, it helped the students to optimize their creativity, structure their knowledge, and sharpen their focus. It is also boost the students' ability to memorizeand remember the point of their ideas.Summing up the result of the study, mind mapping can be effectively implemented in the teaching learning writing, as it provides creativity for both students and teacher.

\section{REFERENSI}

Adam. 2017. Improving Students' Reading Comprehension of Descriptive Texts through Cognitive Strategy at Grade VII-2 of SMPN I Indra Praja Tembilahan. Journal Anglo-Saxon, Vol.8(2) :166-177.

Brown Douglas H. 2001.Teaching by Principles: An Interactive Approach LanguagePedagogy. San Fransisco, CA: Longman.

Brown Douglas H. 2004.Language Assessment: Principle and Classroom Practice. San Fransisco, CA: Longman.

Buran, A.\&Filyukov, A. 2015. Mind Mapping Technique in Language Learning. Procedia Social and Behavioral Sciences 206 (2015).215-218. 
Cheung, Y.L. 2016.Teaching Writing. In W.A. Renandya, \& H.P. Widodo (Eds.), English Language Teaching Today: Building a Closer Link Between Theory and Practice. New York, NY: Springer International

Fulwiler, Toby. 2002. College Writing: A Personal Approach to Academic Writing Third

Edition. Portsmouth, NH: Boynton/Cook Publisher, Inc.

Ilker,et all. 2016. Comparison of Convenience Sampling and Purposive Sampling. American Journal of Theoretical and Applied Statistics, Vol. 5(1).1-4.

Khoiriyah. 2014. Increasing the Students' Writing Skill through Mind Mapping Technique. Nusantara of Research.Vol 1(2).177-187.

Krasnic, Toni.2011. How to Study with Mind Maps. Concise books publishing.

Linse, Caroline T. 2005. Practical English Language Teaching: Young Learners. New York:Mc Grow-Hill.

Nurlaila, A.P. 2013. The Use of Mind Mapping Technique in Writing Descriptive Text.Journal of English and Education. Vol 1(2).9-15.

Pandey, Prabhat. 2015. Research Methodology: Tools and Techniques. Romania: Bridge Center.

Rogers, Henry. 2005. Writing System: A Linguistic Approach. Malden: Blackwell Publishing.

Rustler, Florian. 2012. Mind Mapping for Dummies. Chichester: John Wiley \& Sons, Ltd.

Spoorthi, B. R, Chippagiri, P, and Pandurangappa.R. 2013. Mind Mapping- an effective learning adjunct to acquire a tsunami of information. International Journal of Scientific and Research Publications. Volume 3, No. (12).

Sugiyono. 2011. Statistika untuk penelitian. Bandung: Alfabeta.

Suyanto, Adi. 2010. The Effectiveness of Mind Mapping to Teach Writing Skill Viewed from Their IQ. Sebelas Maret University.

Wrick, Jean. 1987. Steps to Writing Well. New York: Rinehart and Winston. Inc. 